\title{
ALLERGIC VOMITING IN AN INFANT
}

\author{
BY
}

H. S. BRODRIBB, D.M. (Oxon.)

\section{Honorary Anaesthetist, Royal East Sussex Hospital; Temporary Captain (Graded Physician) R.A.M.C.}

Food allergy is well recognized as a cause for such general reactions as asthma, eczema, or urticaria. Bray (1931) states that it is especially frequent in children, and also mentions such contact reactions as blistering of the lips, vomiting, diarrhoea, shock, and even death in hypersensitive infants. Paterson and Forest Smith (1940) discussing infantile eczema state that the allergen in the majority of cases is lactalbumin. A case is now described in which vomiting was the only obvious symptom. This fact led to a considerable delay in the diagnosis, which was mistaken for a defect of digestion.

\section{Case history}

The patient was a boy, a second child, weighing $7 \mathrm{lb} .13 \mathrm{oz}$. at birth. His elder sister has shown no signs of allergy of any kind. His mother was in the habit of drinking liberal quantities of milk, both before and after each of them was born. He was entirely breast fed until the age of five months, and did extremely well. No cow's milk was given in the neonatal period. If anything, he was slightly overfed, doubling his birth weight at just over four months. From five months he was given, occasionally, a few teaspoonfuls of diluted cow's milk (which had been brought to the boil and cooled) with a little cereal or a patent food. This was invariably vomited except on the first two or three occasions, when small quantities were taken. Attempts were repeated at intervals of a few weeks. Further attempts were made with diluted or citrated milk only, and the vomiting was more severe.

A detailed description may be worth recording, as it seems, now, to be significant:

No more than two ounces were taken and often much less. He then seemed tired, began to yawn, salivate, and cough. About a minute or two later, violent gastric contractions could be felt and often heard, and a straining copious vomit was produced consisting of saliva and gastric juice, and containing the small quantity of milk that had been taken. After this he was exhausted, and refusing further food, went to sleep. This was in strong contrast to the small, free-flowing vomit which occasionally occurred after a breast feed, and after which he often demanded more.

The possibility of hypersensitivity had been considered by this time, but in the absence of any other signs, such as eczema, and after discussing it with other medical friends, it was discounted as being unlikely. No redness or swelling of the lips had been noticed.

By the time he was $7 \frac{1}{2}$ months old, weaning from the breast appeared more urgent, and cow's milk was abandoned for ' humanized' dried milk, which had been found to give good results in other infants. This was only tried on three occasions because the vomiting and exhaustion were more severe. On the third occasion when he was over eight months old, erythema was noticed in the folds of his neck where it had rubbed his bib, which was wet with the food. A piece of lint, moistened with the food, and on which had been sprinkled some of the dried powder, was applied to the intact skin of the forearm, and bound on for twenty minutes. An intense erythema and an urticarial wheal about $\frac{3}{4}$ inch in diameter developed. The erythema persisted for some hours. A similar patch test was done with unheated cow's milk, and this took one hour before a positive but less marked reaction was obtained.

All attempts at giving cow's milk were stopped, and the advice of Dr. C. F. Harris, Physician to the Children's Department of St. Bartholomew's Hospital, was sought. 'Almata' was tried at his suggestion, and apart from an occasional slight vomit, without the partial collapse, feeds were taken well. At the same time mixed feeding was started rapidly, the same cereals as before, eggs, gravy, vegetables, and bread, were all retained, and obviously enjoyed. Digestion seemed quite normal, and by $9 \frac{1}{2}$ months, he was completely weaned from the breast. Anything containing cow's milk was still avoided.

Investigation. Attempts were now made to identify the protein acting as allergen. Cow's milk contains 3 per cent. casein, $0 \cdot 5$ per cent. lactalbumin, and about $0 \cdot 1$ per cent. lactoglobulin. The humanized dried milk used contains 0.8 per cent. casein, 0.6 per cent. lactalbumin and 0.26 per cent. lactoglobulin (about $5 \cdot 1$ per cent. lactalbumin and $2 \cdot 25$ per cent. globulin in the dried powder). Also, the humanized dried milk is dried at a temperature below $145^{\circ} \mathrm{F}$. which retains as far as possible the proteins in their natural state. On the other hand, Almata contains casein, egg yolk, and wheat flour proteins, but no lactalbumin or lactoglobulin except, perhaps, minute traces.

With these facts in mind, further patch tests were done on the arms: 


\begin{tabular}{|c|c|c|}
\hline Agent & Duration & Result \\
\hline $\begin{array}{l}\text { Almata powder . } \\
\text { Dried pure casein (twice).. } \\
\text { Pure lactalbumin .. } \\
\text { Casein (obtained by acidifi- } \\
\text { cation and washing of } \\
\text { cow's milk) } \\
\text { Whey (obtained from jun- } \\
\text { ket) } \\
\begin{array}{ccc} & \ldots & \ldots \\
\text { Secway powder } & \ldots & \ldots\end{array}\end{array}$ & $\begin{array}{l}2 \text { hours } \\
45 \text { min. } \\
45 \text { min. } \\
15 \text { min. } \\
60 \mathrm{nim} . \\
30 \mathrm{~min} .\end{array}$ & $\begin{array}{l}\text { Negative } \\
\text { Negative } \\
\text { Negative } \\
\text { Negative } \\
\text { Erythema } \\
\text { and faint } \\
\text { wheal } \\
\text { Positive but } \\
\text { rather less so } \\
\text { than with } \\
\text { humanized } \\
\text { dried milk }\end{array}$ \\
\hline
\end{tabular}

These results were taken to indicate that he was insensitive to casein, either dried or in the natural state. Whey gave a positive test and contains the natural lactalbumin and globulin. Secway is a preparation of whey, dried below $145^{\circ} \mathrm{F}$. and it contains, in the powder, about 11 per cent. albumin and 2.5 per cent. globulin. A pure specimen of lactalbumin, soluble in water, gave a negative test. It was thought that this must have been prepared from cow's milk, though that fact could not be confirmed. Unfortunately no other pure specimens could be obtained in time.

It is stated that acidification of boiled milk may render it harmless in these cases. The probable explanation is that the protein ceases to act as an allergen, in proportion to its transfer into the coagulated state. It appears that these proteins become 'denatured' on boiling at the normal $\mathrm{pH}$ of milk (6.6). They are not completely coagulated, except by boiling at their isoelectric point. This is pH 4.7 for lactalbumin, and pH 5.5 for lactoglobulin (Hawk and Bergeim, 1938).

Patch tests, using the humanized dried milk, were also done at various intervals:

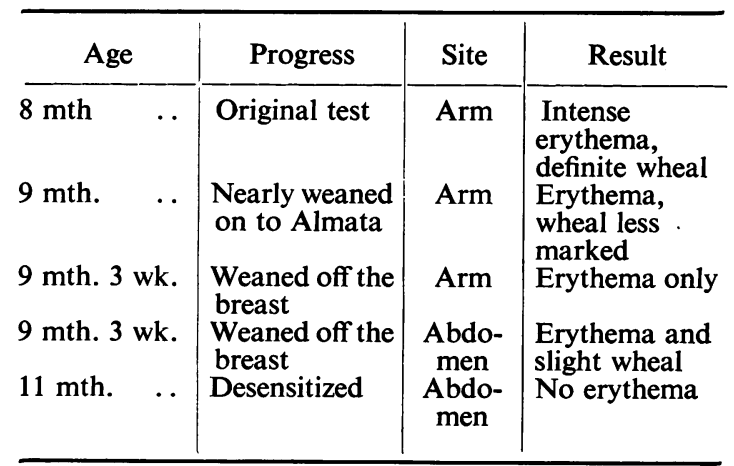

These tests suggest that the sensitivity was decreasing either spontaneously or because of minute traces of allergen in Almata causing slight desensitization. They demonstrated that the skin of the abdomen is more likely to give a positive test in doubtful cases.

Desensitization. Specific desensitization by mouth was carried out on the advice of Dr. Harris. This was done between the tenth and eleventh month, that is, after breast feeding had stopped. The dose of boiled milk given by mouth was doubled each day. The initial dose was 1 drop of 1 in 8 suspension of milk in water; 1 drop of whole milk was given on the fourth day, and so on, until a whole pint had been taken in one day. Since then he has continued to take unmodified boiled milk as freely as any other food, and no sign of any allergic phenomenon has occurred in the subsequent twelve months. He has also taken unboiled T.T. milk, Secway and humanized dried milk, both standard, and specially prepared for him at about $195^{\circ} \mathrm{F}$. by the manufacturers.

All this seems to indicate that he is desensitized, not only to denatured protein, but to protein in the natural state.

Family history. Bray points out that the stronger the hereditary influence, the earlier the age at which symptoms of allergy will have their onset. Detailed enquiries (see diagram) show that in this case, although the parents are not affected, cases of allergy occur in the families of all four grandparents. Every attempt has been made to verify these cases, most of whom are still alive; no doubtful case has been included. It will be seen that there is a strong tendency to migraine in the family of the paternal grandfather. This was produced in every case, that can still be confirmed, by eating particular types of food, e.g., beef, eggs, milk. This effect ceased in each case at about the age of 60 .

\section{Discussion}

It has been shown that the vomiting was an allergic reaction. The proof rests on (1) the result of withdrawing the cow's milk; (2) the skin tests; (3) the result of a course of desensitization. The allergen appeared to be either lactalbumin or lactoglobulin. The points against lactalbumin are: (1) the negative patch test with the specimen available, and (2) Secway gave no stronger reaction than humanized dried milk, and contains more than twice the amount of lactalbumin, but a comparable amount of globulin. The point against globulin is the small quantity of it in cow's milk. It is probably true that these proteins always occur together in the preparation of dried milk so that the exact identity of the allergen is not of practical importance. However, since it is generally agreed that lactalbumin is to blame, it is regretted that patch tests could not have been done with pure specimens of each, known to have been obtained from cow's milk. This seems to be worth doing in similar cases, where such specimens are available.

The points to be observed in the diagnosis appear to be:

(1) The type of vomiting.

(2) Family history of allergy.

(3) The skin tests.

(4) Therapeutic test by trial of appropriate food.

Skin tests may be criticized as unreliable. Bray believes, that while this may be so in adults, they are much more likely to give useful confirmatory evidence in children. They are more definite in cases of sensitivity to cow's milk if dried milk powder is used, especially if the food is prepared at a low temperature. If cow's milk or reconstituted 


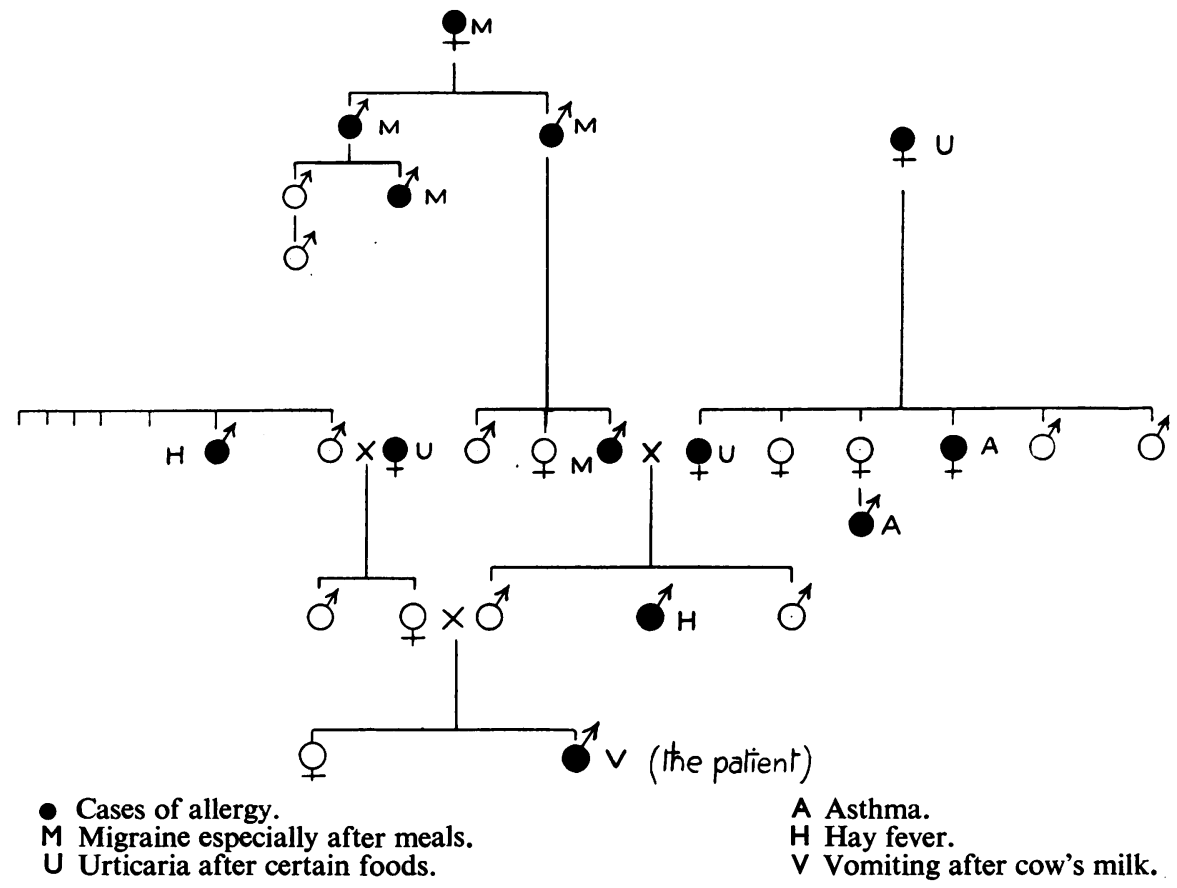

milk is used on the intact skin it should be applied for at least one hour.

As far as it is possible to argue from the experience of one case only, the best line of treatment appears to be: (1) weaning off the breast on to an appropriate food not containing the allergen; (2) specific desensitization by mouth. Almata was successful in this case, and lactic acid milk was not tried. If it is preferred to give it a trial, the method of preparation is described by Paterson and Forest Smith. Also it may be remembered that Cow \& Gate, Ltd., make a food 'Allergilac' in which the quantity of albumin is much reduced and lactic acid is added to produce a $\mathbf{p H}$ of $6 \cdot 0$.

This report is submitted in the hope that it may assist in the early recognition of similar cases. Their accurate diagnosis and treatment is more urgent now when there is so much to discourage prolonged breast feeding. It is felt that although these cases are not rare, insufficient attention has been drawn to their occurrence, and especially to the fact that vomiting may be the only obvious symptom.

\section{Summary.}

(1) A case of an infant, allergic to cow's milk is described.
(2) The only symptom was vomiting, and this confused the diagnosis with that of defective digestion.

(3) The allergen was lactalbumin or lactoglobulin.

(4) Weaning was successful on to a food which omitted these proteins.

(5) Specific desensitization by mouth was completely effective.

Thanks are due to Dr. C. F. Harris, Physician to the Children's Department, St. Bartholomew's Hospital, for his advice on the treatment of this case, and his criticism of this report, to Keen, Robinson \& Co., Ltd., makers of Almata, for their information and samples of casein and lactalbumin, and also to Trufood, Ltd., for their information and for preparing a special sample of their food.

\section{REFERENCES}

Bray, G. W. (1931). Recent advances in allergy, Lond., $90,343,347,350$.

Harris, C. F. (1943). Private communication.

Hawk, P. B., and Bergeim, O. (1938). Practical physiological chemistry, Lond., eleventh ed., 164, 199.

Paterson, D., and Forest Smith, J. (1940). Modern methods of feeding in infancy and childhood, Lond., seventh ed., 78, 149. 